\title{
Editorial to the special issue on natural hazards and risk research in Russia
}

\author{
Sven Fuchs ${ }^{1}$ D $\cdot$ Alexandr Shnyparkov ${ }^{2} \cdot$ Vincent Jomelli $^{3} \cdot$ \\ Nikolay Kazakov ${ }^{4} \cdot$ Sergey Sokratov $^{2}$
}

Received: 24 June 2017/ Accepted: 27 June 2017/Published online: 11 August 2017

(C) The Author(s) 2017. This article is an open access publication

\begin{abstract}
The contributions of this special issue are centered on Russian natural hazard and risk research in the territory of the Russian Federation and the former Soviet Union. The overall aim is to promote the excellent research results in this scientific field which were, unfortunately, for decades only available to the Russian-speaking community. Despite the considerable research efforts undertaken by Russian scholars, methods and results are hardly known among non-Russian researchers and consequently neglected by the international research community simply because many sources are only available in Russian language. A prominent example includes the textbook "The fundamentals of avalanche science" by Bozhinskiy and Losev (1998), the Russian version originally published in 1987, which was only translated due to an initiative of the Swiss Federal Institute of Snow and Avalanche Research in Davos, Switzerland. Following a discussion among participants of the Third International Conference on Debris Flows in YuzhnoSakhalinsk in September 2014, we strongly believe that making accessible Russian research to the international hazard community will be of vital interest and will provide substantial added value to the progress in natural hazard and risk research.
\end{abstract}

Electronic supplementary material The online version of this article (doi:10.1007/s11069-017-2976-2) contains supplementary material, which is available to authorized users.

Sven Fuchs

sven.fuchs@boku.ac.at

1 Institute of Mountain Risk Engineering, University of Natural Resources and Life Sciences, Vienna, Austria

2 Faculty of Geography, M.V. Lomonosov Moscow State University, Moscow, Russian Federation

3 CNRS-UMR 8591, University Paris 1 (Panthéon-Sorbonne), Paris, France

4 Far East Geological Institute, Russian Academy of Sciences, Yuzhno-Sakhalinsk, Russian Federation 
Below, an overview on the historical roots of research on different hazard types in Russia is provided, and major findings that influenced the Russian research efforts are reported. The second section introduces the different interdisciplinary articles of this special issue that summarize the state of the art in Russian research activities. The main aim was not to provide classical articles presenting case studies, but to allow the individual contributors to reflect on their opinion on findings for the ongoing scientific debates. Moreover, the voice in this special issue was given to Russian colleagues working in Russia which means to collect opinions of current research that are (or should be) influential on worldwide research activities.

Furthermore, on the Web page of the Natural Hazards journal at Springer accompanying this article a movie can be downloaded reporting on the first real-scale debris flow tests performed by the "Kazakh Scientific Research Institute for Hydrometeorology" in the early 1970s, until now one of the only in situ experiments on such a scale. This movie is an excellent example for the world-leading research activities at that time; the translation and voice-over were made possible through collaboration between Lomonosov Moscow State University, Russia, and the University of Natural Resources and Life Sciences in Vienna, Austria.

\section{Natural hazard research in Russia}

The history of natural hazard research in Russia can be divided into several successive periods. First studies on hazardous events trace back to the end of the eighth century, when various chronicles were established (Borisenkov and Pasetskii 1988). As for other regions of the world such as Europe (Keiler and Fuchs 2010), the information in these documents was mainly qualitative, and the most prominent hazard types recorded were floods, droughts, windstorms, hail and severe frosts. The descriptions chronicled included the geographical location of individual events, some spatial characteristics and the observed consequences. These roots of natural hazard research are supplemented by higher sophisticated observations once knowledge on hazard triggers increased, and are as such comparable to the development of scientific research in other regions such as for example Central Europe (Pfister 1999; Fuchs and Keiler 2013).

More quantitative scientific investigations on the territory of the contemporary Russian Federation started in the middle of the nineteenth century, when measurement devices allowed for reproducible observations, and scientific education reached broad levels of population. Since then, the genesis of dangerous natural phenomena, their distribution and conditions of initiation were studied, and quantitative information on floods, earthquakes, tsunamis, landslides, debris flows, snow avalanches, etc. became available. In parallel, the industrial revolution and the invention of new measurement devices allowed to start quantitative studies of most hazard types on the territory of Russia.

In the outgoing twentieth century, the ratification of Russia's "State complex scientifictechnical programme" on "Safety of population and industrial objects accounting the risk of manifestation of natural and technogenic catastrophes" in 1991 can be considered as the starting point of a new era of scientific research on natural hazards and risk. Under this program, much of the previous experience was summarized, and an album of maps of dangerous natural hazards on the territory of Russia was compiled. This album became a base for the "Science Atlas" published by the Ministry of the Russian Federation for Civil Defence, Emergencies and Elimination of Consequences of Natural Disasters together with 
the Russian Academy of Sciences (Shoigu 2005). In the following years, studies on natural hazards and risk were conducted under the umbrella of the "Federal target programmes", "Reduction of risks and abatement of consequences of emergency situations of natural and technogenic character in the Russian Federation for the period until 2010", as well as "Reduction of risks and abatement of consequences of emergency situations of natural and technogenic character in Russian Federation until 2015".

In the subsequent sections, we present briefly the variety of natural hazards on the territory of Russia as well as the main historical developments in scientific research.

\subsection{Earthquakes}

In the nineteenth century, the geological basis for investigations on the nature of earthquakes in Russia was set by I.V. Mushketov and A.P. Orlov, who issued the first Russian catalogue of earthquakes (Mushketov and Orlov 1893). The first electromagnetic seismograph was constructed by B.B. Golitsyn in 1906 (Galitzin 1910), and the development of a method to calculate the position of epicenters made systematic studies on seismicity and the internal structure of Earth's crust possible (Galitzin 1914). B.B. Golitsyn suggested two types of seismic stations to be constructed: (1) tele-seismic stations for registration and study of remote earthquakes and (2) regional seismic stations for local studies (Galitzin 1912). Comprehensive regional seismic studies were related to the industrial development of Siberia, Central Asia, Kazakhstan and the South of the European part of country between 1928 and 1947. The consequences of the catastrophic Ashkhabad earthquake on October 6, 1948, exposed problems in the seismic monitoring and related studies in the country, and stimulated a further development of earthquake prediction and forecast. Furthermore, this event triggered comprehensive studies on earthquake causes, including geological and historical analyses and engineering research of the character of destruction. Due to the socioeconomic development starting in the 1950s, there was a strong need for detailed investigations of seismic hazards in the new developing territories until the 1970s. In parallel, a request to identify locations of nuclear weapon tests around the globe resulted in the development and construction of sensitive seismic equipment, and innovative sensors started to be positioned in adits and boreholes. In 1965, the Resolution of the Presidium of the Academy of Sciences approved the establishment of the "United system of seismic monitoring" in the USSR with reference and local stations. The first automatic seismotelemetric system for the collection and analysis of the seismic information was constructed in 1965 in Uzbekistan. The consequences of the catastrophic earthquakes in Uzbekistan in 1966 gave new impulse to the development of the observational network. A new organizational system was introduced in 1978 and made seismic observations operational. The development of the digital methods in the 1980s forced the government to arrange a settlement with the IRIS Consortium of universities dedicated to the operation of science facilities for the acquisition, management and distribution of seismological data, allowing to provide the USSR seismic stations with modern equipment. This step resulted in an inclusion of the Russian seismic monitoring network into the global one.

The first official normative map of the general (review) seismic regionalization (GSR) on the territory of the USSR was published by G.P. Gorshkov (1937). The studies of various scientists since the outgoing 1940s allowed to change the previously accepted "seismic actualism" approach (earthquakes occur where they happened before) to the seismogenetic two-stage method of seismic hazard assessment with elements of forecast. Practically, all the subsequently compiled GSR maps (1957 by S.V. Medvedev and B.A. Petrushevskii, 1968 by S.V. Medvedev and 1978 by M.A. Sadovskii) were based on this 
method of determination of real and potential earthquake sources and the calculation of the expected shock at the Earth surface. However, up to the GSR map of 1978 such maps were not covering the entire Russian territory with the same data quality but region-specific, because the data used from different regions were collected differently and represented fragments from different regions and republics. Thus, the succeeding GSR map of 1997 was compiled differently, as a set of maps of seismic hazard for different elements at risk, considering different categories of responsibility and lifetime (SNiP 2000). The maps were regularly updated, and the most recent set was compiled in 2016 (Ulomov and Bogdanov 2016).

\subsection{Tsunamis}

The beginning of scientific tsunami studies in Russia can be scheduled with the catastrophic event in Kamchatka of November 5, 1952. A strong earthquake with $M=8.5$ resulted in 2336 fatalities and high economic loss on the north Kuril Islands due to a subsequent tsunami. Almost all settlements at the southeast coast of Kamchatka and on the north Kuril Islands were destroyed. After the event a decision was made to establish a tsunami forecast service and a network of seismic stations in the Far East of Russia. At the beginning, the main activity was to collect and systematize any tsunami characteristics of the Pacific Ocean coastline (Solov'ev and Go 1975). Based on this inventory, the authors published a map of the focus points and tsunami heights along the coastline (Solov'ev and Go 1977). The study of earthquakes triggering tsunami hazards allowed them further to develop a so-called magnitude-geographical criterion, used up to present time in the Russian tsunami forecast service (Zolotukhin and Ivel'skaya 2010). In parallel, mathematical modeling of the tsunami extent, the timing and expected waves heights was developed (Poplavskii et al. 1997) and continuously enhanced (Kaistrenko 2011). An important step was the construction of special equipment to record long waves in the range of the tsunami at the shelf and in the open sea (Zhak and Solov'ev 1971). The maps of tsunami hazard (the possible wave height at a certain position at a coast with a repeatability of once per 50 or 100 years) were compiled and recently updated for all regions of Russia up to a repeatability of once per 1000 years (Pustolyakova 2017).

\subsection{Floods}

Studies on flood hazards in Russia are related to the flood history of St. Petersburg situated in the mouth of Neva River. The November 7, 1824, flood event with a water level of $4.2 \mathrm{~m}$ a.s.l. was the starting point for continuous records of the water level at the Kronstadt gauge (Figs. 1,2). After the event, a competition was announced for flood protection works in St. Petersburg, and the event became a catalyst for the elaboration of structural mitigation. In 1825, Pierre-Dominique Bazaine, director of the Institute of Transportation Engineers, proposed constructing a 22-km-long dam across the Gulf of Finland from Lisy Nos through Kronstadt to Oranienbaum. While at that time the technical feasibility was questioned, the area of St. Petersburg is now protected by a similar dam completed in 2011, extending from Lomonosov northward to Kotlin Island (and the city of Kronstadt) and then turning east toward Cape Lisy Nos near Sestroretsk.

Hydrology as a scientific discipline was formed in the beginning of twentieth century in Russia. The dependence of river runoff on altitudinal belts in mountain regions was studied by D.I. Kocherin. In 1927, he compiled a first map of the mean river runoff in the European part of the USSR (Kocherin 1927). M.A. Velikanov introduced the methods of 


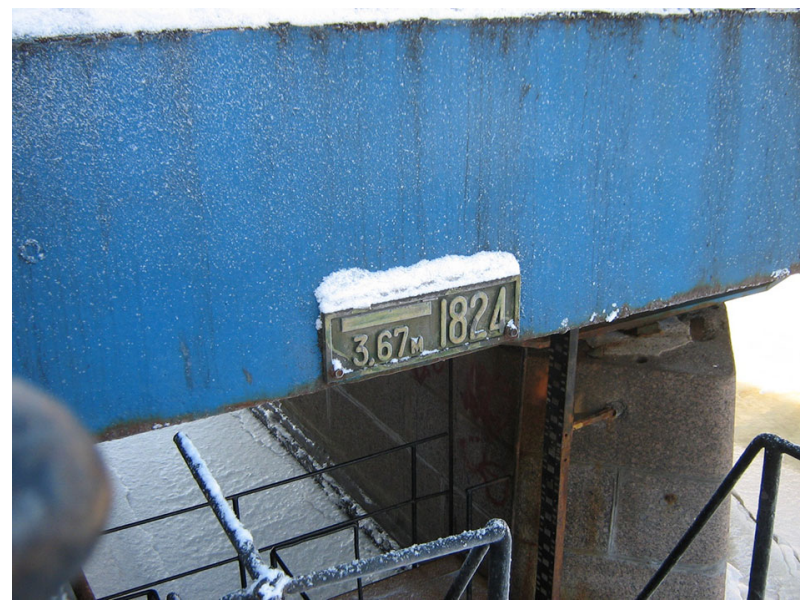

Fig. 1 Kronstadt Fußstock (tide gauge) with the flood water level of 1824. The zero of the Kronstadt gauge in the Gulf of Finland is taken as the basis for all governmental leveling works in Russia and is furthermore the reference height in many other Eastern European countries

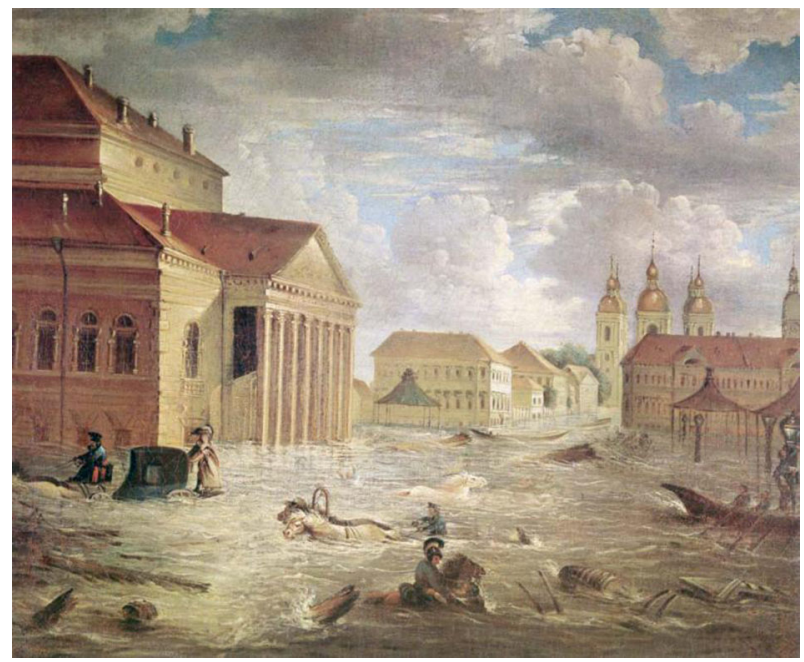

Fig. 2 St. Petersburg's Karuselnaya Square (now Teatralnaya Square) during the 1824 flood. Painting by Fedor Yakovlevich Alekseev (1824)

mathematical statistics for hydrological calculations (Velikanov 1938). At the same time, the idea of a "geographical-hydrological method" of investigations based on possible dependencies between the amount of water in a particular region and the geographical landscape and its components was presented by Glushkov (1933). Mouraveysky 1946 further developed this method and presented the runoff as a geographical factor. The methods of hydrological prognosis started to be developed since the 1930s (Appolov et al. 1960). The first maps of the mean runoff for the territory of the USSR were drawn by Zaikov and Belinkov (1937). The historical distribution of peak flows and floods were analyzed by Zaikov (1954). The "Water cadaster of the USSR" (Sokolovskii 1939-1947) 
was published, later continued by the "Hydrological yearbook." A flood hazard information and forecast service is operational throughout the Russian Federation for all cities and settlements exposed to flood hazards. Recently, the consequences of floods started to be presented following the internationally recognized terminology (see contributions in this special issue).

\subsection{Droughts}

Systematic studies of droughts were started in the second half of the nineteenth century. K.S. Veselovskii made a first attempt to characterize the conditions of humidity and aridity of various climatic zones in Russia (Veselovskii 1857). However, over many years droughts were exclusively considered as negative influence on the crop capacity, and the published catalogues for the territory of Russia were based on data on the crop capacity of grain (Meshcherskaya et al. 2000). A number of the droughts criteria were proposed and different types of droughts were recognized: atmospheric, soil and mixed type (Selyaninov 1928; Pogosyan 1952; Baidal and Uteshev 1959). The conditions of and reasons for the drought formation were in focus of numerous studies during the twentieth century and beyond, involving the network of agro-meteorological stations. This network was established in the 1940s and 1950s and included more than 2000 stations at the peak of development, 1500 of which are still in operation today.

\subsection{Snow avalanches}

Snow avalanches, though not the most dangerous phenomena in terms of quantity of victims and degree of destruction, became one of the major research emphases in Soviet/ Russian risk science. The review of the history of snow avalanche research in Russia can be found in Bozhinskiy and Losev (1998) and in Pudasaini and Hutter (2007) who report the first observations on snow avalanches from the nineteenth century along the Georgian Military Road (an approximately 200-km-long road connection between Tbilisi, Georgia and Vladikavkaz, Russia). It has been repeatedly been stated that the first Russian map of areas endangered by snow and ice avalanches was drawn for this region in 1855 by B.N. Statkovskii. In particular, the region around Mt. Kazbek (5047 m a.s.l.) is well known for the repeating catastrophic snow and ice avalanches affecting the road and in consequence raising the scientific interest on the topic due to the importance of the route for the Russian economy (Palibin 1884). The information on snow avalanche events was included in the "Chronological lists of notable natural events" which was part of the "Kavkazskii kalendar" ("The Caucasian Calendar") annual serial since 1851.

The wide territory of Russia and the variety of climatic regimes requested for a method of hazard assessment based on a combination of geomorphological and meteorological factors responsible for snow avalanches formation. The basis for the "Geography of snow avalanches" was laid in the beginning of 1960s (Tushinskii 1970). The methods of forecast for snow avalanches of different genetic types were subsequently developed by the Hydrometeorological Service of the USSR, and the theories of formation, movement and deposition of snow avalanches were developed (Bozhinskiy and Losev 1998). Further, the mathematical equations to calculate the main dynamical characteristics of snow avalanches were suggested (e.g., Blagoveshchenskii 1991).

At present time, the Russian snow avalanche scientists maintain close contacts with their European and US colleagues. Numerical models such as RAMMS and SNOWPACK are tested and used in the conditions of the Russian regions, and the studies in the field of 
snow avalanche risk are actively developing (Seliverstov et al. 2008; Shnyparkov et al. 2012; Fuchs et al. 2013; Komarov et al. 2016).

\subsection{Debris flows}

The first studies on debris flows were also related to their influence on the Georgian Military Road (Statkovskii 1859). At the end of nineteenth and beginning of the twentieth century, the first descriptions of debris flow processes and their catastrophic consequences were published in Russia (Pyl'tsov 1904). The first regional summaries on debris flows and mitigation measures can be found in the publications of Brilinskii (1936), Trofimov (1937), Kocherga (1937). The most productive period of studies on debris flows was between the 1960s and 1980s: A first summary on the geography of debris flows on the territory of the USSR was prepared by Lopatin (1964), and the cadastre of debris flow basins was published (Raushenbakh 1967; Khmaladze 1969). The first small-scale (1:8,000,000) "Map of the debris flows-endangered regions of the USSR" was constructed in 1975 and published together with a descriptive monograph (Fleishman and Perov 1976). The methods of debris flow investigations and a description of the mechanics of debris flows were summarized (Stepanov 1982; Stepanov and Stepanova 1991). In the 1990s, a first glossary of debris flow process appeared (Perov 1996) and a 1:15,000,000 "Map of the debris flows-endangered regions of the World" (Perov et al. 1997) was published.

The complete bibliography of the Russian, Soviet and post-Soviet scientific publications on all aspects of debris flow research in the country was published for the 1850-1968 period by Vlasov and Krasheninnikova (1969), for the 1969-1991 period by Vlasov (2008) and for the 1992-2009 period by Vlasov (2017).

\subsection{National overview on natural hazards and risk}

The variety of climatic, geological, lithological, geomorphological and orographic conditions determines the presence of practically all possible types of natural hazards at the Russian territory. The Russian communities and industry was numerously affected by different types of dangerous natural phenomena of different extent. The geography of the distribution of the most catastrophic natural hazards is presented in Fig. 3. The most frequent large catastrophic natural hazards were noted in the center of the European part of Russia, the North Caucasus, Primorsky Krai, Sakhalin, Kamchatka. The European part of Russia and Primorsky Krai are mainly exposed to natural hazards related to hydrometeorological processes and events, while North Caucasus, Sakhalin and Kamchatka related to earthquakes, snow avalanches and debris flows.

Annually, 150-250 emergency situations are registered in the territory of Russia. Their dynamics beginning from the 1990s is shown in Fig. 4. The lowest quantity of emergency situations was reported in 1993 (127) and the highest in 1998 (465). The mean quantity of emergency situations is 208, and the mean quantity of fatalities is 142 .

The causes of the natural hazards can be divided as the following: $35 \%$ floods; $19 \%$ strong winds, tornadoes and windstorms; $14 \%$ heavy precipitation; $8 \%$ earthquakes; $7.5 \%$ heavy snowfalls and blizzards; $5 \%$ landslides, rockfalls and debris flows; $3 \%$ intensely cold weather and frost hazards; $2.5 \%$ snow avalanches; $2 \%$ droughts; $1 \%$ hail; and $1 \%$ icing, undercutting and karst collapses. Thus, more than $82 \%$ of all hazards affecting the territory of Russia are of hydrometeorological origin. The seasonal dynamics of hazards for the entire territory of Russia shows a gradual increase in the quantity of emergency situations 


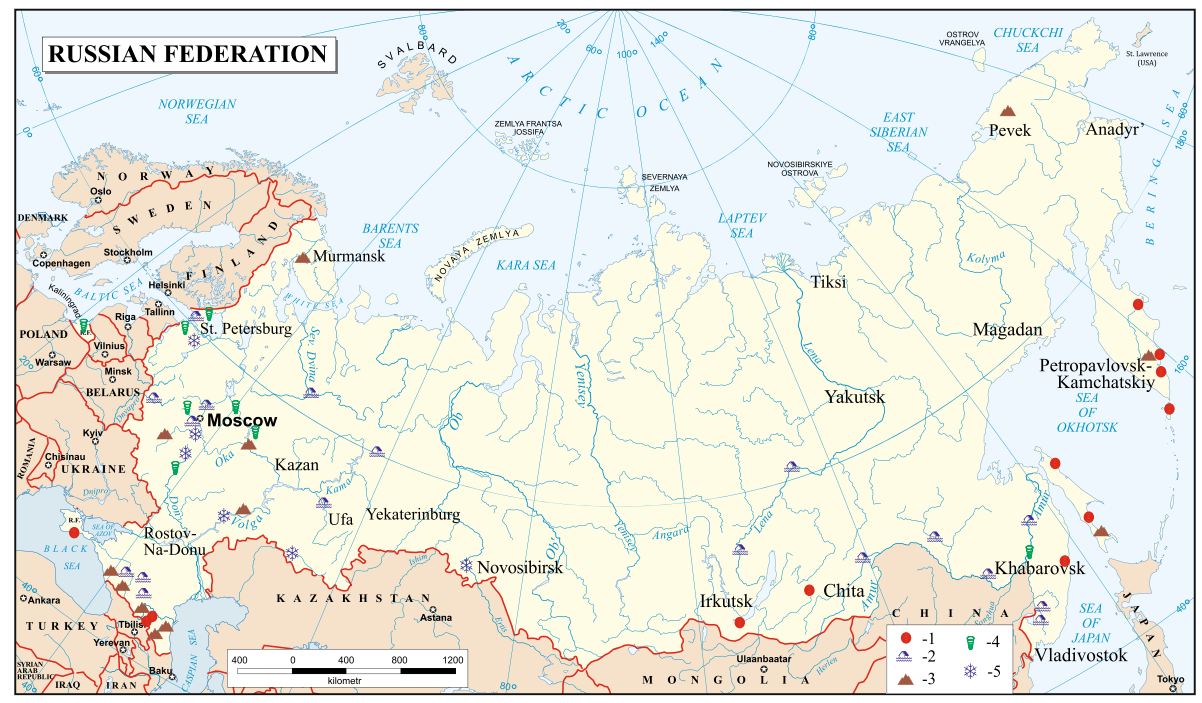

Fig. 3 Distribution of the most catastrophic natural hazards in the territory of Russia (Petrova and Shnyparkov 2004a): 1 earthquakes, 2 floods, 3 landslides, snow avalanches, debris flows, 4 strong winds, tornadoes, 5 frosts, snowfalls, blizzards

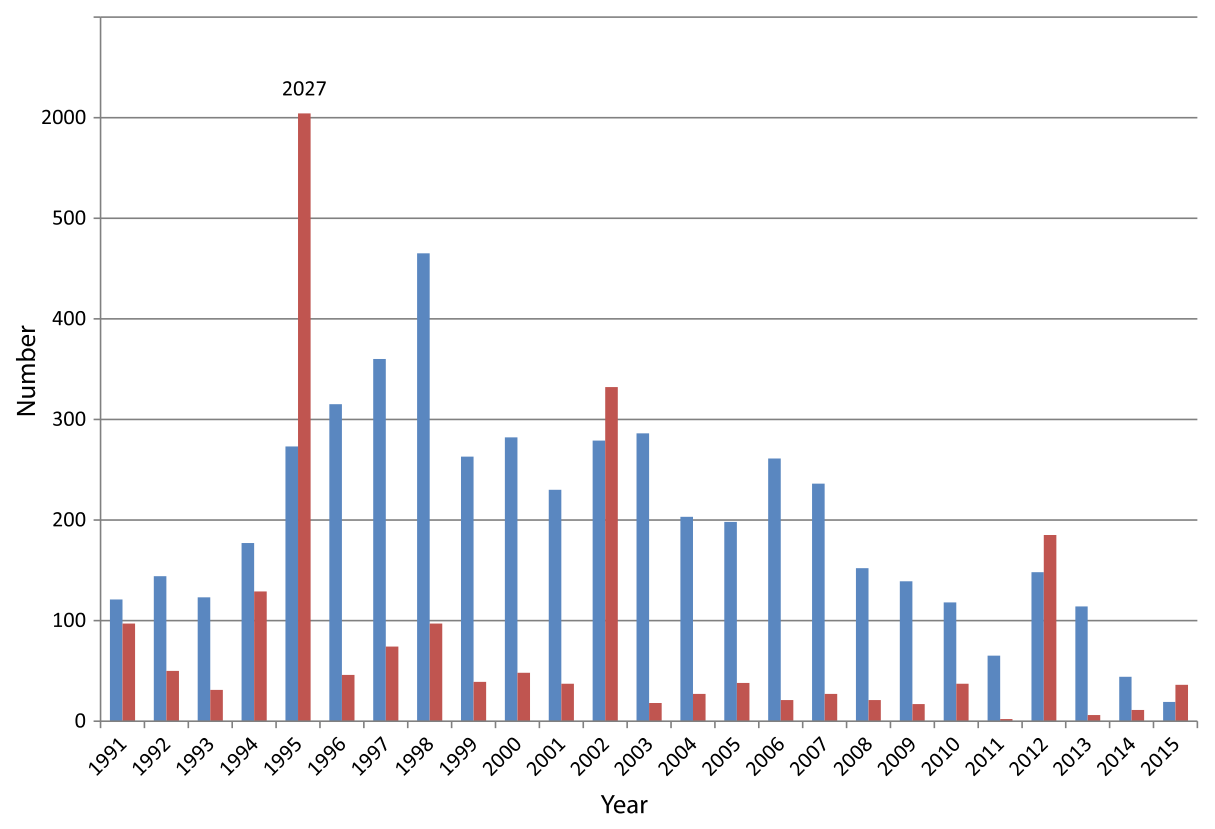

Fig. 4 Dynamics of the emergency situations due to natural hazards in the territory of Russia for the period between 1991 and 2015. The dotted line shows the trend in the number of emergency situations; the solid line shows the dynamics of the number of fatalities because of the natural hazards. Data for 2015 include only January till June 
from winter to summer, following a decrease from summer to winter (Petrova and Shnyparkov 2004b).

The spatial distribution of emergency situations over the territory of Russia is similar in the twenty-first century compared to the past, with a cluster in the Northern Caucasus and along a region spanning from west to east from the center of the European part of Russia along the Kazakhstan border in the south up to the Transbaikal and in the south of the Primorsky Krai, Sakhalin and Kamchatka (Fig. 5).

Floods are prevailing in all regions of Russia except the North-West and Central Federal regions, where strong winds are the dominant hazard type. Annual fatalities are about 30-60 persons with some exceptional years where up to several thousand fatalities are observed. The maximum number of fatalities is a result from endogenic processes, corresponding to $90 \%$ of all fatalities, and $97 \%$ of the victims correspond to earthquakes and floods. Around $70 \%$ of the cities of Russia are exposed (Kurbatova et al. 1997), and in particular, heavy floods are a threat to 190 municipalities, whereas a total of 560 cities are affected by floods of medium and lower magnitudes. Strong winds are possible in all Russian cities, and about 100 settlements were damaged by strong winds and tornadoes in the last decades. About 110 cities are situated in zones affected by strong earthquake zones $(M \geq 7)$ with a population higher than 12 million. Almost everywhere in the country, strong snowfalls and blizzards are possible. The undercutting of river banks resulting in landslides and rockfalls is possible in 550 cities. Tsunami is a threat to 14 cities. Snow avalanches are directly affecting eight cities and indirectly (destruction of communication lines) affecting another 35 cities; these figures for the debris flows are eleven and 32, respectively. The summarized economic loss due to natural hazards in Russia was estimated with 20-40 million US\$ (Osipov 2009).

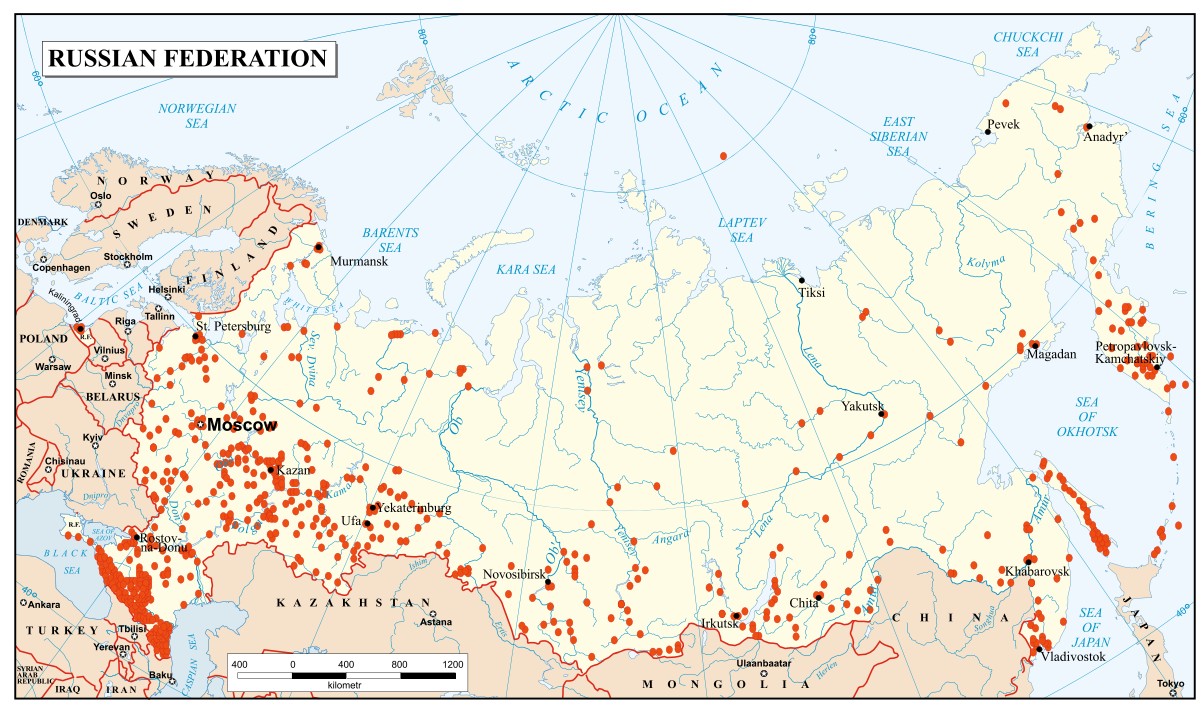

Fig. 5 Spatial distribution of natural emergency situations in the territory of Russia for the period 1990-2009 (without the Crimea) 


\section{Content of individual contributions}

On the national level of the Russian Federation, Osipov et al. (2017) present the most dangerous natural hazards that may cause considerable economic loss as well as fatalities and injuries. The history of studies in the assessment of different natural risk indices with respect to different end users is described, and the conceptual instruments used in the assessment of these indices are discussed. Finally, the principle GIS-based methodical approaches to the assessment and mapping of natural risk are provided. The article concludes with an outlook on future research needs related to nationwide vulnerability assessments.

Approximately $20 \%$ of the territory of the Russian Federation is potentially affected by earthquakes with an intensity of VII and higher (MMSK-86 scale), including the Northern Caucasus, Altai, Sayany, the Baikal area, Yakutia and the Russian Far East, including Kamchatka, Sakhalin Island and the Kuril Islands. Frolova et al. (2016a) address methodological procedures for risk assessment and databases used for risk computation at different scales ranging from national to local. Challenges involved in the application of simulation models and respective input data needed for earthquakes loss estimation are discussed, with a particular focus on information and Web technologies used for verification of data on the built environment and underlying vulnerabilities.

Timely and suitable action immediately after a strong earthquake can result in significant benefits in saving lives and reducing the overall and long-term impact of such events on the economy. Frolova et al. (2016b) describe how prompt and reliable information on losses may enhance emergency response and recovery. In their article, the authors analyze the factors which influence the reliability of earthquake impact simulation under emergency situation with a particular focus on an increase in reliability of loss assessment. The authors show how the reliability of loss assessment output of global models is directly dependent on the quality of input data and on the quality of simulation models. Main constraints on the accuracy and reliability of loss estimation result from input data on earthquake parameters (about 50\%), model assumptions and regional parameters used for intensity simulation (about 30\%), and model assumptions and parameters used for the simulation of damage to buildings and impact on population (about 20\%).

In the contribution of Kazeev and Postoev (2016), pure scientific and applied research on landslide hazard and risk is presented with a focus on both the territory of the Russian Federation and the former Soviet Union. This research included a broad spectrum of studies on landslide processes based on monitoring data collected at specialized stations nationwide, as well as the data collected and analyzed by various government and academic research institutions. The contribution summarizes a vast body of knowledge encompassing an inventory of landslide cases, an overview of mechanisms of landslide development, monitoring and slope stability assessments. A new mechanism-based landslide classification is proposed, and a practical method of increasing slope resistance is presented.

Frolova et al. (2016c) present an evaluation of various aspects of hydrological hazards in the Russian Federation at different scales. A temporal assessment has shown an increase in the number and associated losses of hydrological hazards. With regard to floods, an interesting spatial pattern can be observed: While in the Asian part of the country the number of floods has increased, in estuarine areas in the European part of Russia the number and intensity of floods have significantly reduced since the middle of the twentieth century, especially in the 2000s. It is discussed in the contribution that these dynamics can 
be attributed to flood runoff in the mouths of regulated rivers, with an effective system of flood and ice jam protection. An integrated index accounting for flood hazards and socioeconomic vulnerability was calculated for each region of Russia. Subsequently, a classification of flood risk is presented, taking into account more than 20 hydrological and socioeconomic parameters. Finally, hazard and vulnerability maps for the entire country were generated which can be used for water management and the development of future water resources plans.

The contribution by Shalikovskiy and Kurganovich (2016) proposes a hybrid approach to assess flood risk for the Russian territory combining quantitative and qualitative indicators. The article describes various methods to assess the flood risk, such as likelihood and magnitude of flooding, average annual damage and maximum damage. The authors present two types of flood risk maps: a first type intended to define the mathematical expectation of damage zones for reference buildings with possibility of risk calculation for other buildings using multiple factors and a second type of maps which is designed for the purpose of land use regulation and was based on a priori statistical estimates of flood risk.

Hydrological hazards at river mouths of the Northern Dvina and the Pechora rivers are presented by the contribution of Magritsky et al. (2016). The article is based on results of long-term monitoring, detailed studies and numerical simulation of hydrological hazards at the river mouths of the two major rivers in northern European Russia. Main hydrological hazards described include dangerous ice phenomena, inundations from both pure maximum stream flow and peak discharges with ice jams, surge-induced flooding, wind-induced down-surges, low-water periods and seawater intrusion into the delta branches. These hazards repeatedly caused significant socioeconomic loss and environmental damage to the adjacent riparian areas. Causes and characteristics of hydrological hazards have been evaluated and considered with respect to features, pattern and factors of their long-term, seasonal and spatial variability using statistic methods, remote sensing data and numerical simulation. Furthermore, the impact of regional climate change and economic activities is discussed.

The contribution of Agafonova et al. (2016) deals with dangerous ice phenomena on the lowland rivers of European Russia. Based on computation and modeling, the authors present flood dynamics on the basis of observations of 300 hydrological stations for the period between 1936 and 2013. The dynamics in the characteristics of the ice phenomena occurs under conventionally natural (primarily climatic) and anthropogenic factors. A diversity of natural conditions and degree of climatic changes within European Russia has allowed the authors to identify the main stages of the ice regime changes in the current climatic conditions.

Vinogradova and Vinogradov (2017) report on the experimental results of the artificially triggered debris flows experiments in the Chemolgan river basin, Kazakhstan, 1972-1976. These experiments, organized by the Hydrometeorological Research Institute of Kazakhstan (KSRHI, present successor: Kazhydromet), were the first full-scale experiments with detailed recording of multiple debris flows characteristics in the channel bed of approximately $7 \mathrm{~km}$ length. While some of the results have already been available to the international scientific community (e.g., Rickenmann et al. 2003), most of the material is still published in Russian (Khonin et al. 1976). Given the fact that these experiments were conducted quite early in the history of quantitative scientific research, the results were influential in stimulating further works on erosional and depositional patterns of debris flows. The movie about this experiment is available as online supplement to this special issue. 
Perov et al. (2017) report on regional characteristics of debris flow hazards in Russia. Spatial features of debris flow processes within the country are analyzed, and a map of debris flow hazards in Russia is presented based on a classification of debris flow hazard areas into two zones, six regions and 15 provinces. Furthermore, an inventory of remarkable debris flow events is shown, with some parameters of their magnitude and impact. Major events are reported from Kamchatka-Kuril, the North Caucasus and the Baikal Province.

The contribution of Kazakova et al. (2016) deals with a large-scale assessment of snow avalanche and debris flow hazards in the Sakhalin region, Russian Federation. Their work explores the challenges of hazard assessment for urban areas exposed; more than 60 settlements are at risk of snow avalanches and more than 30 settlements for debris flow hazards. Data are provided for avalanche and debris flow events that occurred in the Sakhalin region between 1928 and 2015. In their paper, the method for the design of hazard maps is described, providing the starting point for any planning constraints in general settlement planning schemes. These maps further allow conducting an assessment of avalanche and debris flow risk within a short time period for a larger territory and at minimum cost.

The final contribution contained in this special issue is presented by Makitov et al. (2016) on research of hailstorm formation and development over the central part of the Northern Caucasus. The authors report radar observations which provided the basis for further computation and which were carried out continuously from the moment of the first radar echo registration until complete dissipation of the hailstorm. The distribution of the hailstorms first radar echo formation zones over the study area was compiled, and areas with the maximum frequency of the hailstorms first radar echo formation were defined. Hailstorm trajectories were analyzed, and the dynamic parameters of the hail core formation and development were evaluated. The paper ends with a comparison of hail storm characteristics in the Northern Caucasus with the hail storms of Mendoza, Argentina, and Alberta, Canada.

Acknowledgements We would like to express our sincere thanks to the entire team of the Editorial Office of Natural Hazards. Moreover, we would like to acknowledge the efforts of all the reviewers who supported this special issue with their knowledge on different aspects of natural hazard risk management and their constructive advice that helped us and the authors to further develop the individual ideas presented in the papers. We would also like to thank all the colleagues who contributed to this special issue, above all for their patience during the process of manuscript production and revision. The support of the Russian Science Foundation Grant No. 16-17-00104 "Snow avalanches and debris flows risk at the territory of Russia: estimation, forecast and mitigation measures" is highly appreciated.

Open Access This article is distributed under the terms of the Creative Commons Attribution 4.0 International License (http://creativecommons.org/licenses/by/4.0/), which permits unrestricted use, distribution, and reproduction in any medium, provided you give appropriate credit to the original author(s) and the source, provide a link to the Creative Commons license, and indicate if changes were made.

\section{References}

Agafonova SA, Frolova NL, Krylenko IN, Sazonov AA, Golovlyov PP (2016) Dangerous ice phenomena on the lowland rivers of European Russia. Nat Hazards. doi:10.1007/s11069-016-2580-x

Appolov BA, Kalinin GP, Nikanorova SN (1960) Gidrologicheskie prognozy [Hydrological prognosis]. Gidrometeoizdat, Leningrad (in Russian)

Baidal MK, Uteshev AS (1959) O sopryazhennosti yavlenii zasukh evropeiskoi territorii SSSR i severnoi poloviny Kazakhskoi SSR [On conjugacy of the droughts events at the European part of the USSR and 
the northern part of the Kazakh SSR]. Trudy KazNIGMI [Trans Kazakh Sci Res Hydro-Meteorol Inst] 11:130-144 (in Russian)

Blagoveshchenskii VP (1991) Opredelenie lavinnykh nagruzok [Determination of avalanches' loading]. Alma-Ata, Gylym (in Russian)

Borisenkov EP, Pasetskii VP (1988) Tysyacheletnyaya letopis' neobychnykh yavlenii prirody [Thousandyears chronicle of unusual natural events]. Mysl', Moscow (in Russian)

Bozhinskiy A, Losev K (1998) The fundamentals of avalanche science [Osnovy lavinovedenija] (trans: BARTELT tftRbCE), vol 55. Mitteilungen des Eidgenössischen Instituts für Schnee- und Lawinenforschung. Eidgenössisches Institut für Schnee- und Lawinenforschung, Davos

Brilinskii AL (1936) Gornye potoki, ikh priroda i mery bor'by s nimi [Mountain torrents, their nature and methods to control them]. Zakgiz, Tiflis (in Russian)

Fleishman SM, Perov VF (1976) Seleopasnye raiony Sovetskogo Soyuza [Debris flows-endangered regions of the Soviet Union]. MSU, Moscow (in Russian)

Frolova NI, Larionov VI, Bonnin J, Sushchev SP, Ugarov AN, Kozlov MA (2016a) Seismic risk assessment and mapping at different levels. Nat Hazards. doi:10.1007/s11069-016-2654-9

Frolova NI, Larionov VI, Bonnin J, Sushchev SP, Ugarov AN, Kozlov MA (2016b) Loss caused by earthquakes: rapid estimates. Nat Hazards. doi:10.1007/s11069-016-2653-X

Frolova NL, Kireeva MB, Magrickiy DV, Bologov MB, Kopylov VN, Hall J, SemenovV A, Kosolapov AE, Dorozhkin EV, Korobkina EA, Rets EP, Akutina Y, Djamalov RG, Efremova NA, Sazonov AA, Agafonova SA, Belyakova PA (2016c) Hydrological hazards in Russia: origin, classification, changes and risk assessment. Nat Hazards. doi:10.1007/s11069-016-2632-2

Fuchs S, Keiler M (2013) Space and time: coupling dimensions in natural hazard risk management? In: Müller-Mahn D (ed) The spatial dimension of risk-how geography shapes the emergence of riskscapes. Earthscan, London, pp 189-201

Fuchs S, Keiler M, Sokratov S, Shnyparkov A (2013) Spatiotemporal dynamics: the need for an innovative approach in mountain hazard risk management. Nat Hazards 68(3):1217-1241. doi:10.1007/s11069012-0508-7

Galitzin B (1910) Ueber einen neuen Seismographen für die Vertikalkomponente der Bodenbewegung (Nachrichten d. Seismischen Kommission, Bd. IV, Lief. 2). Buchdruckerei der Kaiserlichen Akademie der Wissenschaften, St. Petersburg

Galitzin BB (1912) Die neue Organisation des seismischen Dienstes in Russland. Nachrichten der Seismischen Kommission, Bd. IV, Lief. 3, pp 33-49

Galitzin BB (1914) The determination of the epicentre of an earthquake from two observed azimuths// Izvestiya Imperatorskoi Akademii Nauk, Ser. VI [Proceedings of the imperial academy of sciences, ser. VI], vol VIII, no. 15, pp 1137-1156

Glushkov VG (1933) Geografo-gidrologicheskii metod [Geographical-hydrological method]. Izvestiya GGI [Proceedings of the State Hydrological Institute 57-58], pp 5-9 (in Russian)

Gorshkov GP (1937) Seismicheskoe raionirovanie territorii SSSR [Seismic regionalization of the territory of the USSR]. In: Vsesoyuznoe soveshchanie gj antiseismicheskomu stroitel'stvu [All-union conference on anti-seismic construction]. Printing House of the Moscow Institute of Surdomute, Moscow, pp 5-8 (in Russian)

Kaistrenko VM (2011) Tsunami recurrence versus tsunami height distribution along the coast. Pure Appl Geophys 168(11):2065-2069. doi:10.1007/s00024-011-0288-0

Kazakova E, Lobkina V, Gensiorovskiy Y, Zhiruev S (2016) Large-scale assessment of avalanche and debris flow hazards in the Sakhalin region, Russian Federation. Nat Hazards. doi:10.1007/s11069-0162431-9

Kazeev A, Postoev G (2016) Landslide investigations in Russia and the former USSR. Nat Hazards. doi:10. $1007 / \mathrm{s} 11069-016-2688-\mathrm{Z}$

Keiler M, Fuchs S (2010) Berechnetes Risiko - Mit Sicherheit am Rande der Gefahrenzone. In: Egner H, Pott A (eds) Geographische Risikoforschung. Zur Konstruktion verräumlichter Risiken und Sicherheiten. Erdkundliches Wissen 147. Franz Steiner, Stuttgart, pp 51-68

Khmaladze GN (1969) Katalog seleopasnykh rek na territoriyakh Severnogo Kavkaza i Zakavkaz'ya [The catalogue of the debris flows-endangered rivers of the North Caucasus and Transcaucasia]. Tbilisi (in Russian)

Khonin RV, Mochalov VP, Zems AE (1976) Eksperimental'nyi poligon v basseine r. Chemolgan i istoriya ego sozdaniya [The experimental site in the Chemolgan River basin and the history of its founding]. In: Vinogradov YB, Kirenskaya TL (eds) Selevye potoki [Debris flows], Iss. 1. Gidrometeoizdat, Moscow, pp 7-25 (in Russian)

Kocherga FK (1937) Gornomeliorativnye raboty v UzSSR [Mountain melioration activity in Uzbek SSR]. Izdatel'stvo Komiteta Nauk UzSSR, Tashkent (in Russian) 
Kocherin DI (1927) Srednii mnogoletnii, godovoi i mesyachnyi stok v Evropeiskoi chasti Soyuza [The mean long-term, annual and monthly run-off in the European part of Union]. Trudy Moskovskogo instituta inzhenerov transporta [Transaction of the Moscow Institute of the Transport Engineers], vol 6, pp 55-94 (in Russian)

Komarov AY, Seliverstov YG, Glazovskaya TG, Turchaninova AS (2016) Risk assessment in the North Caucasus ski resorts. Nat Hazards Earth Syst Sci 16(10):2227-2234. doi:10.5194/nhess-16-2227-2016

Kurbatova AS, Myagkov SM, Shnyparkov AL (1997) Prirodnyi risk dlya gorodov Rossii [Natural risk for the cities of Russia]. Scientific-Research and Survey Institute of Ecology of a City, Moscow (in Russian)

Lopatin GV (1964) Seli v SSSR i mery bor'by s nimi [Debris flows in USSR and measures to control them]. Nauka, Moscow (in Russian)

Magritsky D, Lebedeva S, Skripnik E (2016) Hydrological hazards at mouths of the Northern Dvina and the Pechora rivers, Russian Federation. Nat Hazards. doi:10.1007/s11069-016-2673-6

Makitov VS, Inyukhin VS, Kalov HM, Kalov RH (2016) Radar research of hailstorm formation and development over the central part of Northern Caucasus (Russia). Organization and main results of the regional hail suppression projects. Nat Hazards. doi:10.1007/s11069-016-2433-7

Meshcherskaya AV, Blazhevich VG, Golod MP, Belyankina IG (2000) Monitoring zasushlivosti na territorii osnovnykh zernoproizvodyashchikh hfionov SNG za poslednee stoletie [Monitoring of the aridity of the main grain-crops producing regions of CIS for the last century]. Trudy VNIISKhM [Proceedings of the all-Russia Institute of Agricultural Meteorology] 33:41-63 (in Russian)

Mouraveysky SD (1946) Protsess stoka kak geograficheskii factor [The process of drain as a geographic factor]. Izvestiya AN SSSR, Ser. geogr. i geofiz. [Proc Acad Sci USSR Ser Geogr Geophys] X(3):293-300 (in Russian)

Mushketov I, Orlov A (1893) Katalog zemletryasenii Rossiiskoi Imperii (Zapiski Imperatorskogo Russkogo geograficheskogo obshchestva po obshchei geografii, t. XXVI) [The catalogue of the earthquakes of the Russian Empire (Notes of the Imperial Russian Geographical Society on the general geography, vol XXVI)]. Tipografiya Imperatorskoi Akademiii Nauk, St.-Petersburg (in Russian)

Osipov VI (2009) Prirodnye opasnosti i strategicheskie riski v mire i v Rossii [Natural hazards and strategic risks - in the world and in Russia]. Ekologiya i zhizn' [Ecol Life] 11-12(96-97):5-15 (in Russian)

Osipov VI, Larionov VI, Burova VN, Frolova NI, Sushchev SP (2017) Methodology of natural risk assessment in Russia. Nat Hazards. doi:10.1007/s11069-017-2780-Z

Palibin N (1884) Sbornik svedenii o zavalakh, upavshikh s gory Kazbeka s 1776 po 1878 god na VoennoGruzinskuyu dorogu [The collection of data on the slides, which felt on the Georgian Military Road from 1776 till 1878]. Tipografiya Glavnogo Upravleniya Namestnika Kavkazskogo i A.A. Mikhel'sona, Tiflis (in Russian)

Perov VF (1996) Selevye yavleniya. Terminologicheskii slovar' [Debris flows. Terminological glossary]. MSU, Moscow (in Russian)

Perov VF, Artyukhova IS, Budarina OI, Glazovskaya TG, Sidorova TL (1997) Map of the world mudflow phenomena. In: Chen CL (ed) Debris-flow hazards mitigation: mechanics, prediction, and assessment. ASCE, New York, pp 322-331

Perov V, Chernomorets S, Budarina O, Savernyuk E, Leontyeva T (2017) Debris flow hazards for mountain regions of Russia: regional features and key events. Nat Hazards. doi:10.1007/s11069-017-2841-3

Petrova EG, Shnyparkov AL (2004a) Spatial distribution of natural and technogenic emergencies in Russia and in the world. In: Malkhazova SM, Chalov RS (eds) Geography, society and environment. Volume IV: natural anthropogenic processes and environmental risk. Gorodets Publising House, Moscow, pp 334-340 (in Russian)

Petrova EG, Shnyparkov AL (2004b) Dynamics of natural and technogenic emergencies in Russia and in the world. In: Malkhazova SM, Chalov RS (eds) Geography, society and environment. Volume IV: natural anthropogenic processes and environmental risk. Gorodets Publising House, Moscow, pp 340-346 (in Russian)

Pfister C (1999) Wetternachhersage. 500 Jahre Klimavariationen und Naturkatastrophen. Bern

Pogosyan KP (1952) Izmenenie klinata v svyazi s planom preobrazovaniya prirody zasushlivykh raionov SSSR [Change of climate in relation to the plans of Nature change in arid regions of the USSR]. Gidrometeoizdat, Leningrad (in Russian)

Poplavskii AA, Khramushin VN, Nepop KI, Korolev YP (1997) Opertivnyi prognoz tsunami na morskikh beregakh Dal'nego vostoka Rossii [Operational forecast of tsunami at the sea coasts of the Far East of Russia]. Yuzhno-Sakhalinsk, Vladivostok (in Russian)

Pudasaini SP, Hutter K (2007) Avalanche dynamics: dynamics of rapid flows of dense granular avalanches. Berlin, Springer, p 602 
Pustolyakova E (2017) Sibirskie uchenye otsenivayut opasnost' tsunami na Rossiiskikh poberezh'yakh [Russian scientists assess the tsunami danger at Russian coasts]. Nauka v Sibiri [Sci Sib] 10:4-5 (in Russian)

Pyl'tsov NN (1904) O vnezapnykh navodneniyakh i selyakh v Nukhinskom uezde Elisavetpol'skoi gubernii [On sudden floods and debris flows in Nukhinsk district of Elisavetpol'sk province]. Izvestiya Kavkazskogo otdeleniya IRGO [Proc Cauc Branch Imp Russ Geogr Soc] 17(4):244-282 (in Russian)

Raushenbakh IO (1967) Katalog seleopasnykh rek Kazakhstana, Srednei Azii i Vostochnoi Sibiri [The catalogue of the debris flows-endangered rivers of the Kazakhstan, Central Asia and East Siberia]. Alma-Ata, Almaty (in Russian)

Rickenmann D, Weber D, Stepanov B (2003) Erosion by debris flows in field and laboratory experiments. In: Rickenmann D, Chen CL (eds) Debris-flow hazards mitigation: mechanics, prediction, and assessment. Millpress, Rotterdam, pp 883-894

Seliverstov Y, Glazovskaya T, Shnyparkov A, Vilchek Y, Sergeeva K, Martynov A (2008) Assessment and mapping of snow avalanche risk in Russia. Ann Glaciol 49:205-209. doi:10.3189/ 172756408787814672

Selyaninov GT (1928) O sel'skokhozyaistvennoi otsenke klimata [On agricultural valuation of climate]. Trudy po sel'skokhozyaistvennoi meteorologii [Trans Agric Meteorol] 20:165-177 (in Russian)

Shalikovskiy A, Kurganovich K (2016) Flood hazard and risk assessment in Russia. Nat Hazards. doi:10. 1007/s11069-016-2681-6

Shnyparkov AL, Fuchs S, Sokratov SA, Koltermann K-P, Seliverstov YG, Vikulina MA (2012) Theory and practice of individual snow avalanche risk assessment in the Russian Arctic. Geogr Environ Sustain 5(3):64-81

Shoigu SK (2005) Atlas prirodnykh i tekhnogennykh opasnostei i riskov chrezvychainykh situatsii v Rossiiskoi Federatsii [Atlas of natural and technogenic dangers and risks of emergency situations in Russian Federation]. Dizain. Informatsiya. Kartografiya, Moscow (in Russian)

SNiP (2000) II-7-81* [Construction norms and rules] Stroitel'stvo v seismicheskikh raionakh [Construction in seismic regions]. Gosstroi, Moscow (in Russian)

Sokolovskii DL (1939-1947) Materialy po rezhimu rek SSSR (Vodnyi kadastr) [The data on the USSR rivers regime (The water cadaster)], vol 1-6. Gidrometeoizdat, Moscow, Leningrad (in Russian)

Solov'ev SL, Go CN (1975) Katalog tsunami na vostochnom poberezh'e Tikhogo okeana [The catalogue of tsunami at the east coast of the Pacific Ocean]. Nauka, Moscow (in Russian)

Solov'ev SL, Go CN (1977) Karta ochagov i vysot tsunami v Tikhom okeane [The map of focus points and the tsunami heights in the Pacific Ocean]. GUGK, Moscow (in Russian)

Statkovskii B (1859) Proekt dorogi cherez khrebet Kavkazskikh gor mezhdu urochishchami Kvishety i stantsiei Kobi [The project of the road over the Caucasian ridge between the holes Kvishery and Kobi station]. Zhurnal Glavnogo upravleniya putei soobshcheniya I publichnykh zdanii [J Chief Dir Commun Lines Public Build] 39(2-3):249-282 (in Russian)

Stepanov BS (1982) Osnovnye kharakteristiki selevykh potokov i selevoi massy. Metody izmerenii [The main characteristics of the debris flows and the debris matter. Methods of measurements]. Gidrometeoizdat, Moscow (in Russian)

Stepanov BS, Stepanova TS (1991) Mekhanika selei [Debris flows mechanics]. Gidrometeoizdat, Moscow (in Russian)

Trofimov NM (1937) Selevye vody Turkmenii [The debris flows waters of Turkmeniya]. Turkmengiz, Ashkhabad (in Russian)

Tushinskii GK (1970) Lavinoopasnye raiony Sovetskogo Soyuza [Avalanche-endangered regions of the Soviet Union]. MSU, Moscow (in Russian)

Ulomov VI, Bogdanov MI (2016) Poyasnitel'naya zapiska k komplektu kart obshchego seismicheskogo raionirovaniya territorii Rossiiskoi Federatsii OSR-2016 [Explanatory note to the set of maps of the general seismic regionalization of the territory of Russian Federation GSR-2016]. Inzhenernye izyskaniya [Eng Surv] 7:49-121 (in Russian)

Velikanov MA (1938) Osnovy statisticheskoi teorii vzveshivaniya nanosov [Statistical theory of silt motion]. Meteorologiya i gidrologiya [Russ Meteorol Hydrol] 9-10:107-132 (in Russian)

Veselovskii KS (1857) O climate Rossii [About the climate of Russia]. The Imperial Academy of Sciences, St. Petersburg (in Russian)

Vinogradova TA, Vinogradov AY (2017) The experimental debris flows in the Chemolgan river basin. Nat Hazards. doi:10.1007/s11069-017-2853-z

Vlasov AY (2008) Selevye yavleniya na territorii SSSR i metody bor'by s nimi [Debris flow phenomena and mitigation measures at the territory of USSR]. Sevkavgiprovodkhoz, Pyatigorsk (in Russian) 
Vlasov AY (2017) Selevye yavleniya na territorii stran SNG i metody bor'by s nimi [Debris flow phenomena and mitigation measures in the countries of the Commonwealth of Independent States]. Sevkavgiprovodkhoz, Pyatigorsk (in Russian)

Vlasov AY, Krasheninnikova NV (1969) Selevye yavleniya na territorii SSSR i metody bor'by s nimi [Debris flow phenomena and mitigation measures at the territory of USSR]. MSU, Moscow (in Russian)

Zaikov BD (1954) Vysokie polovod'ya b pavodki na rekakh SSSR za istoricheskoe vremya [High waters and floods at the rivers of the USSR in historical time]. Gidrometeoizdat, Leningrad (in Russian)

Zaikov BD, Belinkov SY (1937) Srednii mnogoletnii stok rek SSSR [Mean annual rivers' run-off in USSR] (Trudy GGI [Proceedings of the State Hydrological Institute], 2). Leningrad, Moscow, Gidrometeorologicheskoe izdanel'stvo (in Russian)

Zhak VM, Solov'ev SL (1971) Distantsionnaya registratsiya slabykh voln tipa tsunami na shel'fe Kuril'skikh ostrovov [Remote registration of weak waves like tsunami at the shelf of Kuril Islands]. Dokl Akad Nauk SSSR 198(4):816-817 (in Russian)

Zolotukhin DE, Ivel'skaya TN (2010) Prostranstvennaya detalizatsiya magnitudno-geograficheskogo kriteriya tsunamiopasnosti zemletryaseniya v raione tsentral'nykh Kuril'skikh ostrovov [Spatial detailing of magnitude-geographic criterion of tsunami-danger earthquakes in central region of the Kuril Islands]. Problemy analiza riska [Issues of Risk Analysis] 7(2):24-33 (in Russian) 